\title{
ANALISIS KINERJA ISLAMIC HUMAN RESOURCES BERDASARKAN METODE MASLAHAH SCORECARD (STUDI KASUS PADA PT. INALUM)
}

\author{
Rodi Syafrizal \\ STAI Pancabudi Perdagangan \\ rodisyafrizal@gmail.com
}

\begin{abstract}
This study discusses the effectiveness of performance based on the Maslahah Scorecard measurement method and reveals the influence of aspects of Maqasid Al-Syariah on the performance of Muslim employees of PT. INALUM. The population in this study were Muslim employees who worked at PT. INALUM which amounted to 1622 employees with a total sample of 94 people responded and then in determining and selecting a sample of researchers using the Convenience Sampling technique. ased on the approach of this study using the Mix Method method. Based on the results of the study it can be concluded that aspects of Maqasid Al-Sharia have a positive and significant effect of $80.8 \%$ on performance while the remaining $19.2 \%$ is influenced by variables outside of this study and based on statistical calculations that the performance of Muslim employees PT. INALUM has a performance with an effective category with a performance score of $89.9 \%$.
\end{abstract}

Keywords: Performance, Islamic human resources, and effectiveness

\begin{abstract}
Abstrak
Penelitian ini membahas mengenai efektifitas kinerja berdasarkan metode pengukuran Maslahah Scorecard serta mengungkap pengaruh dari aspek-aspek Maqasid Al-Syariah terhadap kinerja karyawan muslim PT. INALUM. Populasi dalam penelitian ini adalah karyawan muslim yang bekerja di PT. INALUM yang berjumlah 1622 karyawan dengan jumlah sampel sebanyak 94 orang respondedan kemudian dalam menentukan dan memilih sampel peneliti menggunakan teknik Convenience Sampling. Bedasarkan pedekatannya penelitian ini menggunakan metode Mix Method. Berdasarkan hasil penelitian maka dapat diambil kesimpulan bahwa aspek-aspek Maqasid Al-Syariah memiliki pengaruh positif dan signifikan sebesar $80,8 \%$ terhadap kinerja sementara sisanya sebesar 19,2\% dipengaruhi oleh
\end{abstract}


variabel diluar dari penelitian ini dan berdasarkan hasil perhitungan statistik bahwa kinerja karyawan muslim PT. INALUM memiliki kinerja dengan kategori efektif dengan skor kinerja $89,9 \%$.

Kata Kunci: Kinerja, Islamic human resources, dan Efektifitas

\section{PENDAHULUAN}

Masalah kinerja adalah hal yang tidak akan perna terpisahkan dari SDM karena kinerja merupakan perilaku nyata yang ditampilkan setiap orang sebagai prestasi kerja yang dihasilkan oleh SDM sesuai dengan perannya dalam perusahaan. ${ }^{1}$ Kualitas SDM sangat penting, tak hanya dari sudut ilmu pengetahuan dan teknologi (IPTEK), namun, tak kalah pentingnya pada dimensi spiritual yaitu berupa iman dan taqwa (IMTAQ) dalam kulitas SDM. Kualitas SDM tidak akan sempurna tanpa ketangguhan mental-spiritual keagamaan. ${ }^{2}$ Sumber daya manusia yang mempunyai dan memegang nilai-nilai agama akan lebih tangguh secara rohaniah. Dengan demikian akan lebih mempunyai tanggung jawab spiritual terhadap ilmu pengetahuan serta teknologi. Karena agama merupakan salah satu hal yang memberikan pengaruh yang besar terhadap perkembangan masyarakat terutama dalam hal budaya dan nilai- nilai sosial di dalamnya (social values). ${ }^{3}$

Kendala kinerja yang terjadi pada umumnya terjadi karena diakibatkan kebanyakan dari perusahaan terlalu fokus kepada kewajiban pekerja dan apa yang harus diberikan pekerja kepada perusahaan sebaliknya mengesampingkan hakhak pekerja. Ketimpangan antara hak dan kewajiban SDM inilah yang memicu masalah kinerja, seperti seperti kurang produktifnya karyawan dan tidak efektifnya kinerja karyawan. Oleh karena itu perusahaan perlu menganalisis kinerja karyawan untuk menilai dan mengetahui efektivitas kerja serta mengevaluasi kinerja agar menjadi lebih efektif. lewat Praktek MSDM perusahaan berupayah untuk mengontrol dan mengelolah kirnerja karyawan agar mencapai target yang ditentukan oleh perusahaan. Praktek MSDM juga mempengaruhi persepsi karyawan mengenai seberapa besar perusahaan tempatnya bekerja memperhatikan kesejahteraan mereka dan percaya bahwa sumber daya yang telah mereka berikan pada organisasi akan dibalas melalui kebijakan. ${ }^{4}$ 
PT Indonesia Asahan Aluminium atau lebih dikenal sebagai PT. INALUM merupakan BUMN pertama dan terbesar Indonesia yang merupakan perusahaan yang bergerak dibidang peleburan aluminium. PT. INALUM memiliki karyawan berjumlah jiwa dan terdapat sekitar 1622 jiwa karyawan yang beragama 2.056 Islam tercatat pada tanggal 1 April 2019. Dapat dikatakan SDM PT. Inalum saat ini mayoritas beragama Islam karena sekitar 79\% SDM PT. Inalum adalah seorang Muslim yang mendominasi kinerja SDM yang ada. Sebagai salah satu BUMN yang ada di Provinsi Sumatera utara dengan karyawan mayoritas muslim mencapai 79\% dari keseluruhan karyawannya. Karena itu peneliti tertarik untuk menjadikan PT. INALUM sebagai subjek penelitian ini untuk mengetahui efektivitas kinerja Islamic human resources (SDM Muslim) yang bekerja di PT. INALUM dan mengukur sejauh mana pengaruh dari aspek-aspek Maqasih AlSyariah yaitu terjaga dan terpeliharanya agama (hifzu al-din), jiwa (hifzu al-nafs), keturunan (hifzu al-nasl), akal (hifzu al-'aql) dan harta (hifzu al-mal) sebagai tujuan Syariat Islam yang dijadikan dasar seorang muslim untuk bekerja. Berdasarkan uraian dari fenomena dan penjelasan yang telah dipaparkan sebelumnya, maka penulis tertarik untuk melakukan penelitian yang berjudul "Analisis Kinerja Islamic Human Resources Berdasarkan Metode Maslahah Scorecard "(Studi Kasus Pada PT. INALUM)".

\section{Tinjauan Pustaka}

\section{Sumber Daya Manusia}

Sumber daya manusia adalah kemampuan terpadu dari daya pikir dan daya fisik yang dimiliki individu. Pikiran dan sifatnya ditentukan oleh keturunan dan lingkungannya, sedangkan prestasi kerjanya di motivasi oleh keinginan untuk memenuhi kepuasannya. ${ }^{5}$ Sumber daya manusia (human resources) merupakan individu produktif yang berkerja sebagai anggota bagian dari penggerak suatu organisasi baik itu di dalam intitusi maupun perusahaan yang memiliki fungsi sebagai aset organisasi maupun perusahaan itu sendiri. Definisi sumber daya manusia (SDM) dapat dibagi menjadi tiga pengertian yaitu (1) manusia yang berkerja di lingkungan suatu organisasi (personil, tenaga kerja, pegawai atau karyawan), (2) Potensi manusiawi sebagai penggerak organisasi salam mewujudkan eksistansinya, (3) Potensi yang merupakan aset dan berfungsi sebagai modal (non material) di dalam organisasi bisnis yang dapat diwujudkan 
menjadi potensi nyata secara fisik dan non fisik dalam eksistensi organisasi. ${ }^{6}$ SDM adalah potensi manusiawi sebagai penggerak organisasi dalam mewujudkan eksistensinya. SDM adalah manusia yang bekerja di lingkungan suatu organisasi (disebut juga personil, tenaga kerja, pekerja atau karyawan). ${ }^{7}$

\section{Islamic Human Resources}

Islamic human resources (IHR) secara ensensial adalah bentuk keimanan dari SDM sebagai seorang muslim, terhadap keesaan Allah dan kesadaran tertingginya untuk tunduk sepenuhnya pada kehendak Allah dan kesadaran bahwa dia sangat dekat dengan Allah. Serta memposisikan seakan-akan melihat Allah yang selalu mengawasinya dalam setiap pekerjaan yang dilakukannya, atau Allah selalu berada didalam hati setiap individu IHR kapanpun dan dimanapun. ${ }^{8}$

Untuk itu Islamic human resources sebagai individu muslim harus dapat mempraktekkan agama mereka ditempat kerja dengan mengembangkan lingkungan yang dapat dipercaya dan tulus. Jabnoun, dalam bukunya "Islam dan Manajemen" mengatakan bahwa evolusi Islam telah membuat kontribusi yang sangat penting dalam banyak bidang kehidupan manusia. Berkenaan dengan perkembangan keilmuan mengenai Islamic human resources, Tayeb dengan jelas menggambarkan etika dan nilai-nilai yang harus ikut terapkan di tempat kerja dan bagaimana organisasi-organisai Islam yang berbeda mengelola karyawan mereka. ${ }^{9}$ Sebagaimana Islam mengajarkan bahwasanya kerja adalah bagian dari ibadah. Oleh karena itu, sesuai ajaran Islam bekerja lebih berdedikasi harusnya disepakati dan memiliki ketentuan atas pekerjaannya, karyawan tersebut membenarkan penghasilan dan mata pencahariannya. Pada saat yang sama Islamic human resources seharusnya akan dapat lebih menonjol sebagai teladan bagi orang yang memiliki iman kepercayaan (agama) yang berbeda. Adapun indikator SDM untuk dapat dikategorikan sebagai Islamic human resources apabila telah memenuhi kriteria sebagai berikut: ${ }^{10}$

1) Beriman dan bertakwa kepada Allah SWT. Faktor iman dan taqwa merupakan fundamental kepribadian yang dapat menghasilkan pekerja yang bertanggung jawab dan jujur. 
2) Berbudi pekerti luhur. Iman seorang pekerja akan memancarkan budi pekerti luhur termasuk di dalamnya disiplin, komunikatif, saling menghargai, dapat berkerja tim dengan baik, adil dan bijaksana.

3) Sehat jasmani. Setiap pekerja muslim perlu membina fisiknya melalui berbagai upaya, antara lain memakan makanan yang halal, bergizi baik, olahraga, istirahat serta kerja yang seimbang.

4) Sehat rohani. Meliputi kestabilan mental dalam menghadapi tugas pekerjaan, memiliki semangat dan gairah kerja yang selalu hidup, antusias dan lain sebagainya.

5) Trampil. Ukuran mutlak untuk menentukan SDM yang berkualitas adalah keterampilan (skills) dalam bidang tugas yang dihadapinya.

\section{Kinerja Dalam Perspektif Islam}

Kinerja dalam perspektif Islam merupakan salah satu sarana hidup dan aktivitas yang mempunyai peran yang penting dalam kehidupan sosial. Bekerja sebagaimana dianjurkan oleh agama, bahkan bekerja sering dijadikan tolak ukur untuk menilai seseorang. Menurut ajaran Islam, setiap orang dituntut untuk mandiri. Dengan kata lain, hendaknya seseorang mencukupi kebutuhannya sendiri dengan cara berusaha dan bekerja walaupun berat. Dilihat dari segi ekonomi, bekerja adalah salah satu sarana produksi yang sangat penting disamping modal dan faktor-faktor alam lainnya. ${ }^{11}$

Dalam konsep Islam, bekerja adalah kewajiban bagi setiap manusia, walaupun Allah telah menjamin rezeki setiap manusia, namun rezeki tersebuttidak akan datang kepada manusia tanpa usaha dari orang yang bersangkutan. Oleh karena itu, jika seseorang ingin berkecukupan dan sejahtera, ia harus bekerja. ${ }^{12}$ Ajaran Islam menyampaikan pesan bahwa kerja dan agama itu sendiri adalah sumber motivasi yang besar bagi umat Islam. Seorang muslim tahu bahwa ketika dia sedang bekerja, dia sedang dalam ibadah pada Allah dan itu adalah motivator yang kuat dalam dirinya sendiri yang mebuat dirinya terlepas dari keuntungan material apapun. Sumber motivasi tidak terbatas pada standar hidup dan pemenuhan diri yang lebih tinggi tetapi itu melingkupi fakta bahwa pekerjaannya adalah perbuatan baik secara moral yang pada akhirnya akan membantu dia untuk mencapai kesuksesan sejati di dunia dan kesejahteraan di akhirat. ${ }^{13}$ 
Ketika seorang Muslim yang bekerja ini berarti bertujuan dengan, setiap pengurangan nilai hadiah duniawi dan materialistis tidak mempengaruhi tingkat motivasi dan kinerjanya. ${ }^{14}$ Sebagaimana dijelaskan dalamAl- qur'an Surah AtTaubah/09:105.

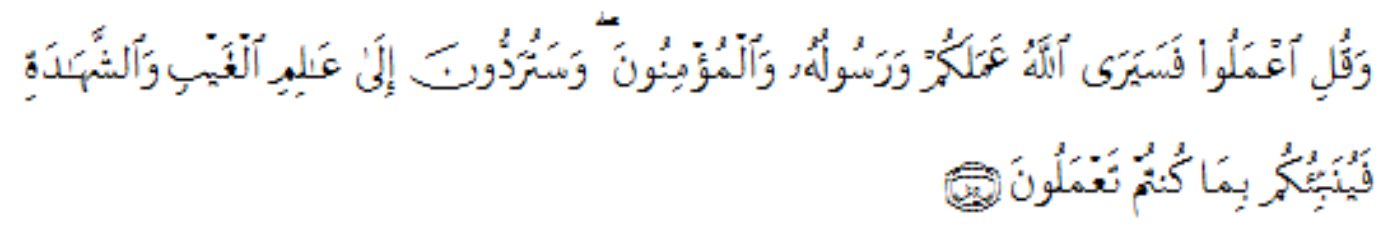

Artinya: dan Katakanlah: "Bekerjalah kamu, Maka Allah dan Rasul-Nya serta orang-orang mukmin akan melihat pekerjaanmu itu, dan kamu akan dikembalikan kepada (Allah) yang mengetahui akan yang ghaib dan yang nyata, lalu diberitakan-Nya kepada kamu apa yang telah kamu kerjakan. ${ }^{15}$

Adapun indikator kinerja dalam persfektif Islam sebagai berikut berdasarkan hasil penelitian Alimuddin yang mengemukakan terdapat empat elemen penilaian kinerja yang sesuai dengan perspektif Islam yaitu: ${ }^{16}$

1) Material, adalah keuntungan atau laba yang cukup untuk memenuhi kebutuhan rumah tangga yang diperoleh dengan cara jujur, tidak merugikan orang lain dan digunakan untuk investasi demi keberlangsungan hidup perusahaan.

2) Mental, yaitu dalam melakukan sebuah pekerjaan hendaknya dilakukan dengan tekun dan perasaan bahagia, menikmati hasil yang diperoleh, dan menumbuhkan kepercayaan diantara sesama.

3) Spritual, yaitu lebih mendekatkan diri kepada Allah SWT. Menganggap bekerja sebagai sarana ibadah kepada Allah SWT. Selalu merasa bersyukur dengan hasil yang diperoleh dan tetap taat dan konsisten dengan aturan serta hukum-hukum Allah.

4) Persaudaraan, yaitu terciptanya hubungan sosial yang harmonis baik dalam lingkungan perusahaan maupun lingkunganmasyarakat sekitar dengan memberikan pekerjaan kepada orang-orang miskin, berbagi dengan masyarakat sekitar, memenuhi kebutuhan masyarakat dengan produk dan jasa yang halal dan memiliki kualitas tinggi dengan harga terjangkau.

\section{Maslahah}

Secara umum maslahah adalah upaya memelihara tujuan syari'ah dan meraih segala bentuk kemanfaatan atau menolak segala hal kemudharatan yang 
merusak. Al Ghazali menjelaskan bahwa tujuan utama segala aktivitas adalah keselamatan hidup diakhirat dan kesuksesan hidup didunia. Inilah yang dimaksud dengan falah dan untuk mencapai falah seorang muslim harus memperjuangka maslahah yang mencakup pencapaian tujuan syariat islam, yang berdasarkan pada Maqasid Al-Syari'ah (tujuan hukum Islam). ${ }^{17}$ Maslahah pada dasarnya adalah ungkapan dari menarik manfaat dan menolak mudarat, tetapi bukan itu yang kami maksud sebab menarik manfaat dan menolak mudarat adalah tujuan makhluk (manusia), dan kebaikan makhluk itu akan terwujud dengan meraih tujuan-tujuan mereka. Yang kami maksud dengan maslahah ialah memelihara tujuan syariat atau hukum islam, dan tujuan syariat dari makhluk itu ada lima, yaitu memelihara agama, jiwa, akal, keturunan (ada yang menyatakan keturunan dan kehormatan), dan harta mereka. Setiap yang mengandung upaya memelihara kelima hal prinsip ini disebut maslahah dan setiap yang menghilangkan kelima prinsip ini disebut mafasadat. ${ }^{18}$

\section{Tujuan dan Manfaat Penilaian Kinerja}

Pengukuran atau penilaian terhadap kinerja perlu dilakukan untuk mengetahui apakah selama pelaksanaan kinerja terdapat deviasi dari rencana yang telah ditentukan, atau apakah kinerja dapat dilakukan sesuai jadwal waktu yang ditentukan, atau apakah hasil kerja telah tercapai sesuai dengan yang diharapkan. ${ }^{19}$ Penilaian kinerja merupakan salah satu proses dalam sistem pengendali manajemen dengan membandingkan dan mengevaluasi antara rencana yang dibuat dan hasil yang dicapai, menganalisa penyimpangan yang terjadi dan melakukan perbaikan. ${ }^{20}$ Dalam Islam, pengukuran kinerja karyawan harus didasarkan pada keadilan, akuntabilitas dan tanggung jawab. Untuk memastikan ini terjadi, penilaian harus dilakukan secara adil sebaik-baiknya sebagaimana menjalankan SDM melaksanakan amanat dari perusahaan. Dalam proses penilaian tidak boleh mempublikasikan kelemahan karyawannya (SDM) dan diskriminasi berdasarkan ras, suku, warna kulit atau pun agama. Tujuan dilakukannya penilaian kinerja agar mengetahui produktitas atau prestasi kerja SDM dalam memenuhi standart kerja dan target kerja yang memberikan kontribusi dalam pencapaian tujuan perusahaan. ${ }^{21}$ Sebagaimana diketahui bahwa kesejahteraan dari kepuasan kerja memiliki hubungan timbal balik atas kinerja yang dilakukan maka Maslahah daruriyyah sebagai kebutuhan dasar atau kebutuhan pokok yang harus dipenuhi setiap umat Muslim yang terdiri dari agama atau keimanan (ad-din), 
jiwa atau kehidupan (an-nafs), keturunan atau keberlangsungan (al-nasl), harta atau kesejahteraan (al-mal), dan akal (al-aql). Kelima tujuan hukum Ilahi Islam ini harus dicapai, karena mereka terletak di lingkaran kebutuhan esensial (dharuriyyat) yang mutlak harus dipenuhi guna mewujudkan kesuksesan hidup di dunia dan keselamatan hidup di akhirat. Yang dapat diartikan sebagai persyaratan dasar dalam Islam yang harus dipenuhi untuk setiap individu muslim. ${ }^{22}$ Sesuai dengan tujuan utama syariah itu sendiri dalam untuk melayani kepentingan dan menyelamatkan manusia dari bahaya dari segala bentuk kemudharatan. Oleh karena itu dalam mengukur kinerja Islamic human resources, maka Maslahah daruriyah merupakan konsep yang harus digunakan untuk menilai tercapainya kemaslahatan suatu kinerja yang telah dilakukan oleh Islamic human resources itu sediri sebagai tolak ukur dari hasil kerja yang telah ia lakukan. ${ }^{23}$ Sebagaimana dapat dijelaskan melalui gambar berikut: ${ }^{24}$

\section{Gambar 1 Pengembangan Manusia dan Kesejahteraan Berbasis Maqasid Al-Syari'ah}



\section{Maslahah Scorecard}

Maslahah Scorecard atau (MaSC) yaitu merupakan sistem pengukuran kinerja berbasis Maqasid Al Syari'ah dengan landasan konsep maslahah. Sistem pengukuran kinerja ini didukung oleh beberapa alat manajemen yaitu empat varibel Balanced Scorecard (BSC) sebagai variabel pengukuran dan siklus Plan (perencaan) -Do (pelaksanaan) - Check (pemeriksaan) - Action (pengambilan keputusan atau tindakan) dikenal dengan singkatan (PDCA) sebagai metodologi pengukuran kinerja. Sistem kinerja MaSC dikembangkan dengan mempertimbangkan pendekatan "RADAR" yang berarti results (hasil), approach (pendekatan), deploy (menyebarkan), assess (menilai) dan refine (memperbaiki). 
MaSC mengukur kinerja dengan berorientasi pada hasil. Sistem ini terintegrasi dengan perencanaan dan pengembangan pendekatan yang menghubungkan pencapaian disaat ini dan di masa datang. ${ }^{25}$

Pengukuran kinerja yang baik yaitu pengukuran yang mampu menggambarkan seluruh aktiftas Islamic human resources dan lingkungan kerja serta mengetahui masalahan kinerja IHR, target kinerja, memasukan ukuran yang bersifat persepsi juga memiliki indikator kinerja, memasukan unsur efektifitas kinerja, memiliki sistem yang jelas untuk menterjemahkan strategi organisasi kedalam ukuran-ukuran kinerja dan yang terakhir, sistem pengukuran kinerja harus berpola pada perbaikan berkelanjutan. ${ }^{26}$ Sistem kinerja MaSC terdiri atas lima aspek Maqashid Al-Syari'ah pengukuran kinerja yang masing-masing aspek semua lima tujuan Syariah ini yaitu, keimanan (ad-din), jiwa atau kehidupan (an$n a f s$, keturunan atau keberlangsungan (al-nasl), harta atau kesejahteraan (al-mal), dan akal (al-aql) harus dicapai, karena terletak pada bagian dari kebutuhan (Dharuriyyat) yang dapat diartikan sebagai persyaratan dasar dalam Islam yang harus dipenuhi untuk setiap individu muslim. Sehingga pengukuran kinerja IHR juga harus sampai batas tertentu mencakup semua tujuan Syariat Islam. ${ }^{27}$

\section{Penelitian Terdahulu}

Kajian terhadap penelitian terdahulu dilakukan dengan tujuan untuk membandingkan penelitian dan mendukung penelitian ini adalah sebagai berikut:

Tabel 1 Penelitian Terdahulu

\begin{tabular}{|c|l|l|l|}
\hline No. & \multicolumn{1}{|c|}{$\begin{array}{c}\text { Nama } \\
\text { Peneliti }\end{array}$} & \multicolumn{1}{|c|}{ Judul Penelitian } \\
\hline 1. & $\begin{array}{l}\text { Bilal Khan, } \\
\text { Ayesha } \\
\text { Farooq dan } \\
\text { Zareen } \\
\text { Hussain }\end{array}$ & $\begin{array}{l}\text { Human Resources } \\
\text { Management: An } \\
\text { Islamic perpective }\end{array}$ & $\begin{array}{l}\text { Orisinalitas nilai Sebuah model } \\
\text { konseptual HRM dan Islam disajikan } \\
\text { yang memberikan penjelasan tentang } \\
\text { hubungan antara jalan hidup seorang } \\
\text { muslim dalam penerapan nilai-nilai } \\
\text { islam dalam kinerja SDM dan } \\
\text { akumulasi materialistik. }\end{array}$ \\
\hline 2. & $\begin{array}{l}\text { Ilhaamie } \\
\text { Abdul Ghani } \\
\text { Azmi }\end{array}$ & $\begin{array}{l}\text { Islamic Human } \\
\text { Resource Practices } \\
\text { And Organizational } \\
\text { Performance: } \text { A } \\
\text { Study } \text { On Malaysian } \\
\text { Islamic }\end{array}$ & $\begin{array}{l}\text { Menunjukkan bahwa beberapa dari } \\
\text { mereka tidak sepenuhnya menerapkan } \\
\text { praktik sumber daya manusia Islam. } \\
\text { Bisa jadi karena mereka tidak } \\
\text { sepenuhnya menyadari unsur-unsur } \\
\text { praktik atau praktik SDM }\end{array}$ \\
\hline
\end{tabular}


286 AT-TA WASSUTH: Jurnal Ekonomi Islam, Volume IV No. 2 Juli -

Desember 2019: 277 - 300

\begin{tabular}{|c|c|c|c|}
\hline & & Organizations & $\begin{array}{l}\text { konvensional lebih dominan dalam } \\
\text { organisasi-organisasi ini. Namun, } \\
\text { dampak pada kinerja organisasi lebih } \\
\text { tinggi dari pada tingkat implementasi. } \\
\text { Ini menunjukkan bahwa praktik } \\
\text { sumber daya manusia Islam lebih baik } \\
\text { dari pada perspektif konvensional } \\
\text { dalam menghasilkan kinerja } \\
\text { organisasi yang lebih tinggi. }\end{array}$ \\
\hline 3. & $\begin{array}{c}\text { Djaelany } \\
\text { Haluty }\end{array}$ & $\begin{array}{l}\text { Islam Dan } \\
\text { Manajemen Sumber } \\
\text { Daya Manusia } \\
\text { Yang Berkualitas }\end{array}$ & $\begin{array}{l}\text { Dalam Islam pengelolaan sumber daya } \\
\text { manusia mengacu pada apa yang } \\
\text { dicontohkan oleh Nabi Muhammad } \\
\text { SAW didasarkan pada konsep Islam } \\
\text { mengenai manusia itu sendiri. Konsep } \\
\text { Pertama: Manusia diciptakan untuk } \\
\text { beribadah kepada Tuhan. Oleh karena } \\
\text { itu segala kegiatan manusia harus } \\
\text { merupakan bentuk ibadah. Konsep } \\
\text { kedua: Manusia adalah khalifatullah } \\
\text { fil ardhli }\end{array}$ \\
\hline 4. & $\begin{array}{l}\text { Tri } \\
\text { Wikaningrum }\end{array}$ & $\begin{array}{l}\text { Praktek Dan } \\
\text { Kebijakan } \\
\text { Manajemen Sumber } \\
\text { Daya Manusia Pada } \\
\text { Perbankan Syariah }\end{array}$ & $\begin{array}{l}\text { Hasil analisis menunjukkan bahwa } \\
\text { praktik manajemen SDM bagi } \\
\text { sebagian besar responden bank syariah } \\
\text { kurang optimal. Hal ini termasuk } \\
\text { alokasi waktu pelatihan dan frekuensi } \\
\text { pelaksanaan, kejelasan dasar untuk } \\
\text { pengaturan promosi, jenis dan jumlah } \\
\text { kompensasi yang kurang kompetitif } \\
\text { bila dibandingkan dengan jenis } \\
\text { pekerjaan yang sama di bank lain, } \\
\text { serta penilaian kinerja yang kurang } \\
\text { berorientasi pada pengembangan } \\
\text { SDM. }\end{array}$ \\
\hline 5. & $\begin{array}{l}\text { Kholid } \\
\text { Musyaddad }\end{array}$ & $\begin{array}{l}\text { Prinsip Prinsip Manaje } \\
\text { Sumber Daya } \\
\text { Manusia Dalam Persp } \\
\text { Islam }\end{array}$ & $\begin{array}{l}\text { Agar mekanisme kerja organisasi } \\
\text { dapat berjalan dengan baik, dan agar } \\
\text { tujuan dapat tercapai secara maksimal, } \\
\text { maka harus diciptakan sistem } \\
\text { manajemen yang terarah pada } \\
\text { terwujudnya efisiensi dan efektifitas } \\
\text { kerja. Manajemen sebagai salah satu } \\
\text { seni dalam memanfaatkan manusia } \\
\text { untuk mencapai tujuan harus dibangun } \\
\text { di atas prinsip prinsip kemanusiaan. }\end{array}$ \\
\hline
\end{tabular}




\begin{tabular}{|c|c|c|c|}
\hline \multirow[t]{2}{*}{6.} & Teguh & Manajemen Sdm & Dengan penerapan Manajemen \\
\hline & Suripto & $\begin{array}{l}\text { Dalam Prespektif } \\
\text { Ekonomi Islam : } \\
\text { Tinjauan Manajemen } \\
\text { Sdm Dalam Industri } \\
\text { Bisnis }\end{array}$ & $\begin{array}{l}\text { Sumber Daya Manusia } \\
\text { karyawan akan tunduk pada } \\
\text { perusahaan sehingga mereka dapat } \\
\text { berpartisipasi secara aktif untuk } \\
\text { kemajuan perusahaan. Sistem } \\
\text { ekonomi Islam dalam menerapkan } \\
\text { manajemen sumber daya manusia, } \\
\text { berdasarkan harmoni atau } \\
\text { keseimbangan antara kebutuhan untuk } \\
\text { melakukan materi dan etika manusia. } \\
\text { Sistem Ekonomi Islam tidak } \\
\text { melupakan fitur utama kemajuan } \\
\text { manusia, yang bergantung pada sejauh } \\
\text { mana kelancaran koordinasi dan } \\
\text { harmoni antara aspek moral dan } \\
\text { material dari kehidupan manusia. }\end{array}$ \\
\hline 7. & $\begin{array}{l}\text { Amiur } \\
\text { Nuruddin }\end{array}$ & $\begin{array}{l}\text { SDM Berbasis } \\
\text { Syariah }\end{array}$ & $\begin{array}{l}\text { kualifikasi dan kualitas sumber daya } \\
\text { manusia adalah tentang integrasi } \\
\text { antara "pengetahuan, keterampilan } \\
\text { dan kemampuan" (KSA) dengan } \\
\text { komitmen moral dan integritas } \\
\text { pribadi. Beberapa aspek moralitas } \\
\text { yang dimaksud di sini adalah } \\
\text { AlShiddiq (benar, jujur), Al-Amanah } \\
\text { (dapat dipercaya, kredibel), Al- } \\
\text { Tabligh (komunikatif) dan Al- } \\
\text { fathanah (cerdas, profesional). Selain } \\
\text { itu, dalam mengelola bisnis, aspek } \\
\text { moral bahkan sebagai "faktor kunci } \\
\text { keberhasilan". }\end{array}$ \\
\hline 8 & Rusindiyanto & $\begin{array}{l}\text { Analisis Kinerja } \\
\text { Sumber Daya } \\
\text { Manusia Dengan } \\
\text { Metode Human } \\
\text { Resources Scorecard } \\
\text { (Hrsc) (Studi Kasus } \\
\text { Di Pt. Arto Metal } \\
\text { Internasional } \\
\text { Sidoarjo) }\end{array}$ & $\begin{array}{l}\text { Hasilnya dapat disimpulkan bahwa } \\
\text { kinerja perspektif keuangan pada } \\
\text { tahun } 2007 \text { sebesar } 2,20 \text { (atau kurang) } \\
\text { dan pada } 2008 \text { sebesar } 4,20 \text { (baik), } \\
\text { perspektif pelanggan pada } 2007 \\
\text { sebesar } 2,57 \text { (atau kurang) dan pada } \\
2008 \text { sebesar } 3,833 \text { ( sedang), } \\
\text { perspektif proses bisnis pada tahun } \\
2007 \text { adalah sebesar } 2,786 \text { (sedang) } \\
\text { dan pada tahun } 2008 \text { sebesar } 3,23 \\
\text { (sedang). Sedangkan untuk proses } \\
\text { pembelajaran dan perspektif } \\
\text { pertumbuhan pada tahun } 2007 \text { adalah }\end{array}$ \\
\hline
\end{tabular}




\begin{tabular}{|c|c|c|c|}
\hline & & & $\begin{array}{l}\text { sebesar } 1,333 \text { (atau kurang) dan pada } \\
\text { tahun } 2008 \text { sebesar } 2 \text { (atau kurang). } \\
\text { Kinerja sumber daya manusia pada } \\
\text { tahun } 2007 \text { berjumlah } 2.091 \text { (atau } \\
\text { kurang), dan pada } 2008 \text { meningkat } \\
\text { menjadi } 3.213 \text { (medium). }\end{array}$ \\
\hline 9 & Eni Haryani & $\begin{array}{l}\text { Analisis Pengukuran } \\
\text { Kinerja Universitas } \\
\text { Islam Negeri } \\
\text { Sumatera Utara } \\
\text { Medan Berdasarkan } \\
\text { Maslahah Scorecard }\end{array}$ & $\begin{array}{l}\text { Hasil penelitian ini menunjukkan } \\
\text { bahwa Hasil Pengukuran kinerja } \\
\text { sebagai berikut : No Nama Variabel } \\
\text { Skor Kriteria Penilaian Skor Kategori } \\
1 \text { Orientasi Ibadah } 60 \% 59,61 \% \\
\text { Rendah } 2 \text { Orientasi Proses Internal } \\
60 \% 68,54 \% \text { Cukup } 3 \text { Orientasi } \\
\text { Pembelajaran } 60 \% 61,56 \% \text { Cukup } 4 \\
\text { Orientasi Bakat } 60 \% 66,27 \% \text { Cukup } \\
5 \text { Orientasi Harta kekayaan } 60 \% \\
67,56 \text { Cukup 6 Orientasi Pelanggan } \\
60 \% 63,51 \% \text { Cukup. }\end{array}$ \\
\hline 10 & $\begin{array}{l}\text { Ahmad } \\
\text { Firdaus, }\end{array}$ & $\begin{array}{l}\text { Maslahah Scorecard } \\
\text { (MaSC), Sistem } \\
\text { Pengukuran Kinerja } \\
\text { Bisnis Berbasis } \\
\text { Maqosid Syari'ah }\end{array}$ & $\begin{array}{l}\text { PT. Asuransi Takaful Keluarga (PT. } \\
\text { ATK) memiliki kinerja hasil } \\
\text { kemaslahatan sebesar 0,692. Secara } \\
\text { kualitatif angka tersebut menunjukan } \\
\text { bahwa PT. ATK memberikan } \\
\text { kemaslahatan bagi stakeholder. Range } \\
\text { kinerja hasil kemaslahatan adalah: } \\
0,000 \text { yang mengindikasikan bahwa } \\
\text { bisnis tidak memberikan kemaslahatan } \\
\text { dan 1,000 yang mengindikasikan } \\
\text { bahwa bisnis memberikan } \\
\text { kemaslahatan. PT. ATK memiliki } \\
\text { kinerja proses kemaslahatan sebesar } \\
0,666 \text {. Secara kualitatif angka tersebut } \\
\text { menunjukan bahwa PT. ATK belum } \\
\text { secara penuh menerapkan sistem } \\
\text { kinerja MaSC.Range kinerja proses } \\
\text { kemaslahatan adalah: 0.000 yang } \\
\text { mengindikasikan bahwa bisnis tidak } \\
\text { melaksanakan kinerja MaSCdan } 1.000 \\
\text { yang mengindikasikan bahwa bisnis } \\
\text { telah melaksanakan kinerja MaSC } \\
\text { secara penuh }\end{array}$ \\
\hline
\end{tabular}




\section{Kerangka Berpikir}

Kerangka berfikir merupakan penjelasan sementara terhadap sesuatu masalah yang menjadi objek penelitian. Kerangka kinerja konseptual Islamic human resources akan memiliki 5 (lima) variabel Maqashid Al-Syar'iah sebagai variabel bebas (eksogen), dimana setiap variabel memiliki 4 (empat) dimensi indikator yang berasal dari 40 dimensi indikator yang dikelompokan Ascarya yaitu sebagai berikut; Sebagaimana seperti yang disajikan dalam gambar sebagai berikut: ${ }^{28}$

Gambar 2 Kerangka Konsentual Kineria Islamic Human Resources

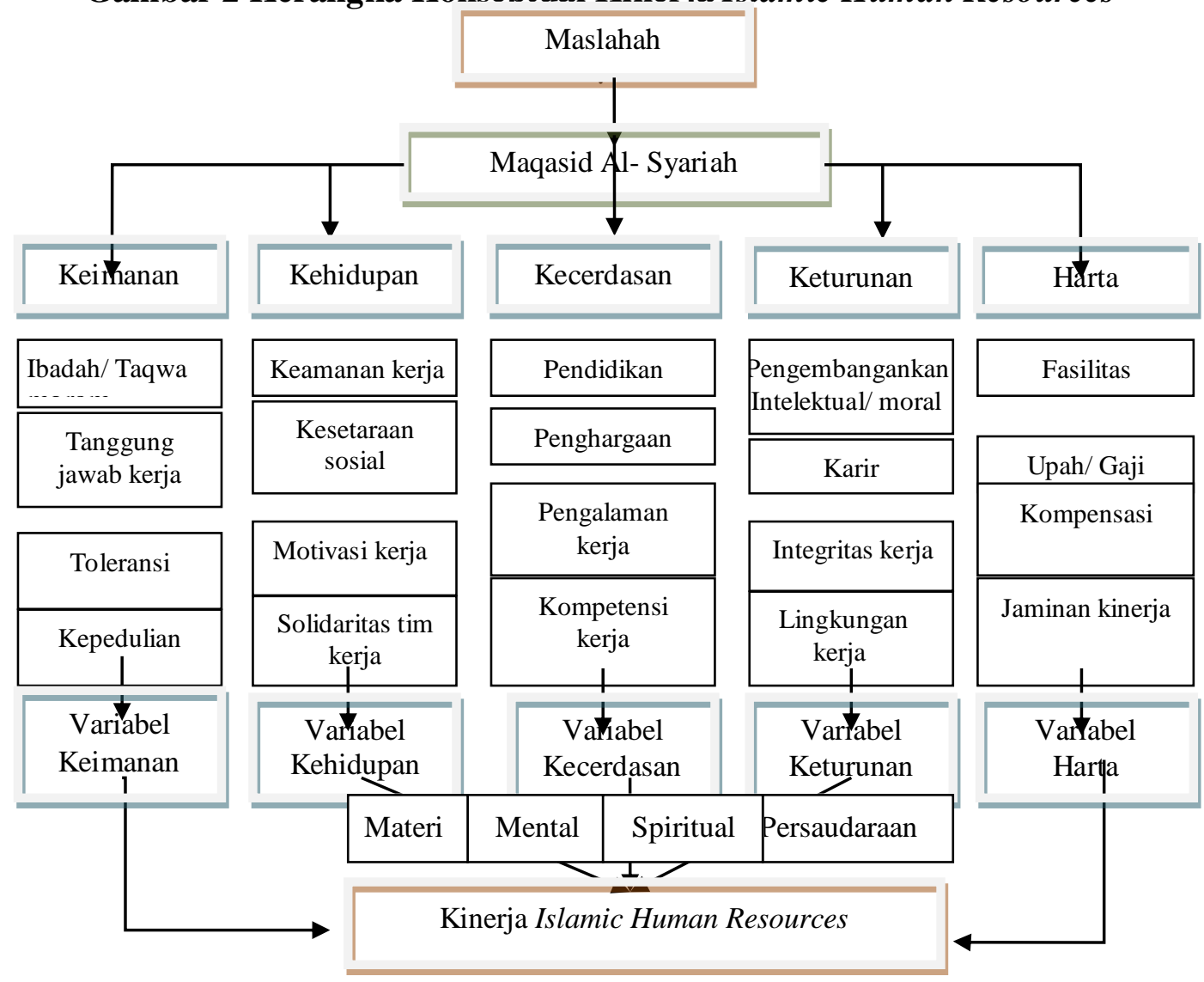

Berdasarkan kajian teori yang telah dijabarkan di atas, maka hipotesis

yang dapat dibuat dalam penelitian ini adalah :

$\mathrm{H}_{\mathrm{a} 1}$ : Ada pengaruh keimanan terhadap Kinerja

$\mathrm{H}_{01}$ : Tidak ada pengaruh keimanan terhadap Kinerja

$\mathrm{H}_{\mathrm{a} 2}$ : Ada pengaruh kehidupan terhadap Kinerja

$\mathrm{H}_{02}$ : Tidak ada pengaruh kehidupan terhadap Kinerja

$\mathrm{H}_{\mathrm{a} 3}$ : Ada pengaruh kecerdasan terhadap Kinerja

$\mathrm{H}_{03}$ : Tidak ada pengaruh kecerdasan terhadap Kinerja

$\mathrm{H}_{\mathrm{a} 4}$ : Ada pengaruh keturunan terhadap Kinerja

$\mathrm{H}_{04}$ : Tidak ada pengaruh keturunan terhadap Kinerja

$\mathrm{H}_{\mathrm{a} 5}$ : Ada pengaruh harta terhadap Kinerja

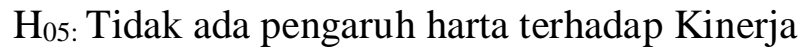




\section{Metode Penelitian}

Metode penelitian yang digunakan dalam peneitian ini adalah Mixed Method mengkombinasikan antara pendekatan kuantitatif yang digunakan untuk menganalisa data staistik dan kualitatif dekskrptif digunakan untuk mendekskripsikan data dan infomasi dengan menganalisis teori yang ada. Data dalam penelitian ini adalah data primer yang diperoleh dari pemberian angket kepada 94 orang karyawan muslim PT. INALUM. Dengan menggunakan skala likert untuk memberikan skor tehadap masing- masing variabel Maqasid AlSyariah yang kemudian diklasifikasikan menjadi beberapa kategori, efektif atau tidak efektifnya. Kemudian dilakukan uji regresi untuk mengetahui sejauh mana variabel Maqasid Al-Syariah mempengaruhi kinerja karyawan PT. INALUM.

\section{Hasil Penelitian Dan Pembahasan}

Kategori kinerja Islamic human resources pada PT. INALUM

Tabel 2 Kriteria Efektivitas Kinerja

\begin{tabular}{|c|c|c|c|c|}
\hline NO. & Nama Variabel & $\begin{array}{c}\text { Skor Kriteria } \\
\text { Penilaian }\end{array}$ & Skor & Kategori \\
\hline 1 & Keimanan & $60 \%$ & $89,1 \%$ & Efektif \\
\hline 2 & Kehidupan & $60 \%$ & $82,8 \%$ & Efektif \\
\hline 3 & Kecerdasan & $60 \%$ & $92,3 \%$ & Efektif \\
\hline 4 & Keturunan & $60 \%$ & $88,6 \%$ & Efektif \\
\hline 5 & Harta & $60 \%$ & $86,1 \%$ & Efektif \\
\hline 6 & Kinerja & $60 \%$ & $89,9 \%$ & Efektif \\
\hline
\end{tabular}

Berdasarkan tabel diatas dapat disimpulkan bahwa 5 aspek Maqasid AlSyariah telah terimplementasi dengan baik pada karyawan muslim PT. INALUM karena miliki kategori efektif hal ini sesuai dengan kinerja karyawan muslim (Islamic human resources) PT. INALUM yang memiliki kategori efektif.

\section{Analisisi Model Pengukuran (Outer Model)}

Model pengukuran ini sendiri digunakan untuk mendeskripsikan atau menggambarkan hubungan antar variabel laten (konstruk) dengan indikatornya menguji validitas konstruk dan reliabilitas instrumen.

\section{Outer Loading}

Tabel 3 Outer Loading

\begin{tabular}{|c|c|c|c|c|c|c|}
\hline ITEM & Keimanan & Kehidupan & Kecerdasan & Keturunan & Harta & Kinerja \\
\hline Item 1 & 0.798 & & & & & \\
\hline
\end{tabular}




\begin{tabular}{|c|c|c|c|c|c|c|}
\hline Item 2 & 0.826 & & & & & \\
\hline Item 3 & 0.790 & & & & & \\
\hline Item 4 & 0.838 & & & & & \\
\hline Item 5 & & 0.741 & & & & \\
\hline Item 6 & & 0.715 & & & & \\
\hline Item 7 & & 0.748 & & & & \\
\hline Item 8 & & 0.756 & & & & \\
\hline Item 9 & & & 0.705 & & & \\
\hline Item 10 & & & 0.706 & & & \\
\hline Item 11 & & & 0.724 & & & \\
\hline Item 12 & & & 0.758 & & & \\
\hline Item 13 & & & & 0.704 & & \\
\hline Item 14 & & & & 0.869 & & \\
\hline Item 15 & & & & 0.860 & & \\
\hline Item 16 & & & & 0.774 & & \\
\hline Item 17 & & & & & 0.798 & \\
\hline Item 18 & & & & & 0.826 & \\
\hline Item 19 & & & & & 0.836 & \\
\hline Item 20 & & & & & 0.706 & \\
\hline Item 21 & & & & & & 0.766 \\
\hline Item 22 & & & & & & 0.864 \\
\hline Item 23 & & & & & & 0.810 \\
\hline Item 24 & & & & & & 0.758 \\
\hline
\end{tabular}

Tabel Outer Loading diatas berfungsi untuk melihat validitas dari pada item yang menjadi indikator terhadap variabelnya.. Pada tabel diatas dapat dilihat bahwa nilai outer loading masing-masing item yang menjadi indikator dalam penelitian ini memiliki nilai outer loading yang melebihi 0.7 yang menjelaskan bahwa semua item yang menjadi indikator dalam penelitian ini adalah valid dan layak menjadi alat ukur masing-masing variabel karenamampu menjelaskan variabelnya masing masing.

\section{Validitas dan Reliabilitas Konstruk}

Validitas dan reliabilitas konstruk (Construct reliability and validity) merupakan pengujian untuk mengukur dan mengetahui sejauh mana kehandalan suatu konstruk pada suatu penelitian

Tabel 4 Validitas dan Reliabilitas Konstruk

\begin{tabular}{|c|c|c|c|c|}
\hline Variabel & $\begin{array}{c}\text { Cronbach's } \\
\text { Alpha }\end{array}$ & Rho_A & $\begin{array}{c}\text { Composite } \\
\text { Reliability }\end{array}$ & $\begin{array}{c}\text { Average Variance } \\
\text { Extracted (AVE) }\end{array}$ \\
\hline Keimanan & 0,829 & 0,832 & 0,886 & 0.661 \\
\hline
\end{tabular}


292 AT-TA WASSUTH: Jurnal Ekonomi Islam, Volume IV No. 2 Juli Desember 2019: 277 - 300

\begin{tabular}{|c|c|c|c|c|}
\cline { 5 - 5 } Kehidupan & 0,731 & 0,743 & 0,829 & 0.548 \\
\hline Kecerdasan & 0,708 & 0,706 & 0,814 & 0.523 \\
\hline Keturunan & 0,817 & 0,836 & 0,879 & 0.647 \\
\hline Harta & 0,803 & 0,817 & 0,871 & 0.629 \\
\hline Kinerja & 0,813 & 0,820 & 0,877 & 0.641 \\
\hline
\end{tabular}

Sumber: : Data primer 2019 diolah dari SmartPLS

Tabel diatas menunjukkan kriteria validitas dan rebilitas yang baik karena telah memenuhi kriteria dan persyaratan dalam pengujian validitas dan reliabilitas konstruk. Data yang telah disebarkan dapat dipercaya dan bisa digunakan sebagai data untuk menjawab pertanyaan penelitian karena telah memenuhi kategori sebagai berikut, 1) Cronbach Alpha: > 0,7, 2) Rho_A: >0,7, 3) Composite Reliability: >0,7, 4) Average Variance Extracted (AVE): > 0,5

\section{Diskriminant Validity}

Discriminant validity nilai ini merupakan nilai cross loading faktor yang berguna untuk mengetahui apakah konstruk memiliki diskriminan yang memadai atau tidak.

Tabel 5 Kriteria Fornell-Larcker

\begin{tabular}{|c|c|c|c|c|c|c|}
\hline Variabel & Keimanan & Kehidupan & Kecerdasan & Keturunan & Harta & Kinerja \\
\hline Keimanan & $\mathbf{0 . 8 1 3}$ & & & & & \\
\hline Kehidupan & 0.521 & $\mathbf{0 . 7 4 0}$ & & & & \\
\hline Kecerdasan & 0.249 & 0.140 & $\mathbf{0 . 7 2 4}$ & & & \\
\hline Keturunan & 0.693 & 0.575 & 0.44 & $\mathbf{0 . 8 0 5}$ & & \\
\hline Harta & 0.737 & 0.637 & 0.296 & 0.743 & $\mathbf{0 . 7 9 3}$ & \\
\hline Kinerja & 0.763 & 0.622 & 0.492 & 0.811 & 0.789 & $\mathbf{0 . 8 0 1}$ \\
\hline
\end{tabular}

Sumber: Data primer 2019 diolah dari SmartPLS

Dari tabel diatas terlihat bahwa nilai akar kuadrat AVE $(0.813,0.740$, 0.724, 0.805, 0.793, dan 0,801) lebih besar dari korelasi masing-masing konstruk dapat disimpulkan bahwa masing-masing variabel X1 (Keimanan), X2 (Kehidupan), X3 (Kecerdasan), X4 (Keturunan), X5 (Harta) Dan Y (Kinerja) menunjukkan lebih tingggi dari pada indikator lainnya dan dapat disimpulkan bahwa korelasi nilai setiap konstruk lebih tinggi dari pada indikator lainnya. 


\section{Analisis Model Sruktural (Inner Model)}

Model struktural atau inner model merupakan model analisis data yang mendeskripsikan hubungan antar variabel laten (konstruk) yakni eksogen dan endogen serta hubungan diantaranya

Tabel 6 Tabel R Square

\begin{tabular}{|l|l|l|}
\hline Variabel & R Square & R Square Adjusted \\
\hline $\mathrm{Y}$ & 0.808 & 0.797 \\
\hline
\end{tabular}

Sumber: Data primer 2019 diolah dari SmartPLS

Tabel diatas menjelaskan bahwa R-Square Adjusted model jalur dalam penelitian ini $=0.797$. artinya kemampuan variabel X1 (keimanan), X2 (Kehidupan), X3 (Kecerdasan), X4 (Keturunan) Dan X5 (Harta) dalam menjelaskan Y adalah 79.7\%. Dengan demikian model tergolong Subtansial (kuat).

Tabel 7 F Square

\begin{tabular}{|c|c|}
\hline Variabel & Kinerja \\
\hline Keimanan & 0.166 \\
\hline Kehidupan & 0.063 \\
\hline Kecerdasan & 0.192 \\
\hline Keturunan & 0.130 \\
\hline Harta & 0.082 \\
\hline
\end{tabular}

Sumber: Data primer 2019 diolah dari SmartPLS

Berdasarkan nilai F-Square pada tabel diatas dapat disimpulkan bahwa pengaruh dari variabel-variabel eksogen terhadap s variabel endogen memiliki kriteria sebagai berikut:

$$
\begin{array}{lll}
\circ \text { Keimanan } & \longrightarrow \text { Kinerja }=0.166 \text { (sedang) } \\
\circ \text { Kehidupan } & \longrightarrow \text { Kinerja }=0.063 \text { (rendah) } \\
\circ \text { Kecerdasan } & \longrightarrow \text { Kinerja }=0.192(\text { sedang) } \\
\circ \text { Keturunan } & \longrightarrow \text { Kinerja }=0.130 \text { (rendah) } \\
\circ \text { Harta } & \longrightarrow \text { Kinerja }=0.082(\text { rendah })
\end{array}
$$

\section{Pengujian Hipotesis Menggunakan Direct Effect}

Tahapan selanjutnya uji hipotesis menggunakan direct effectberguna untuk menguji hipotesis pengaruh langsung suatu variabel yang mempengaruhi 
(eksogen) terhadap variabel yang dipengaruhi (endogen).Adapun hasil pengujian hipotesis menggunakan direct efefect adalah sebagai berikut:

\section{Gambar 3 Hasil Boostrapping Pengaruh langsung Eksogen Terhadap Endogen}

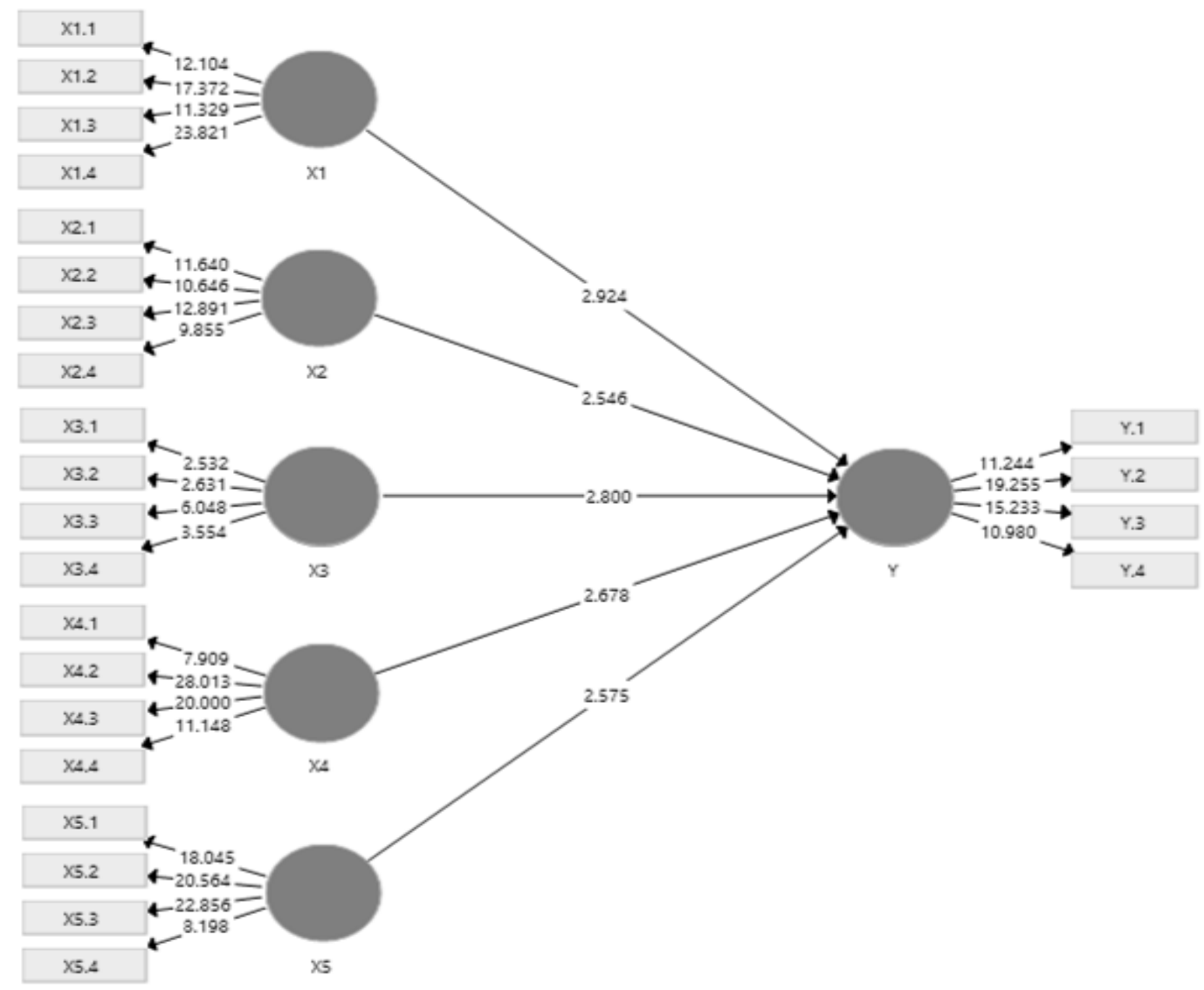

Berdasarkan gambar diatas dapat dilihat bahwa variabelkeimanan memiliki pengaruh langsung terhadap variabel kinerja $(\mathrm{t}=2.924 ; \mathrm{p}<0.05)$. Selanjutnya peran variabel kehidupan juga memiliki pengaruh langsung terhadap variabel kinerja $(\mathrm{t}=2.546 ; \mathrm{p}<0.05)$, variabel Kecerdasan memiliki pengaruh langsung terhadap variabel kinerja $(\mathrm{t}=2.800 ; \mathrm{p}<0.05)$, variabel keturunan memiliki pengaruh langsung terhadap variabelkinerja $(\mathrm{t}=2.678 ; \mathrm{p}<0,05)$, terakhir variabel harta memiliki pengaruh langsung terhadap variabel kinerja $(\mathrm{t}=2.575 ; \mathrm{p}<0,05)$. Maka dapat disimpulkan bahwa seluruh variabel eksogen memiliki pengaruh secara langsung terhadap variabel endogen. 
Tabel 8 Koefisien Jalur (Path Coefficient)

\begin{tabular}{|l|r|r|r|r|r|}
\hline & Sampel Asli (O) & Rata-rata Sampel (M) & Standar Deviasi (STDEV) & T Statistik ( O/STDEV ) & P Values \\
\hline$X 1 \rightarrow Y$ & 0.279 & 0.278 & 0.096 & 2.924 & 0.003 \\
\hline$X 2 \rightarrow Y$ & 0.147 & 0.143 & 0.058 & 2.546 & 0.011 \\
\hline$X 3 \rightarrow Y$ & 0.217 & 0.210 & 0.077 & 2.800 & 0.005 \\
\hline$X 4 \rightarrow Y$ & 0.272 & 0.277 & 0.101 & 2.678 & 0.007 \\
\hline$X 5 \rightarrow Y$ & 0.224 & 0.220 & 0.087 & 2.575 & 0.010 \\
\hline
\end{tabular}

Sumber: Data primer 2019 diolah dari SmartPLS

Berdasarkan tabel diatas dapat diinterpretasikan bahwa nilai koefisien jalur dan nilai probabilitas/ signifikansi (p-value) masing- masing variabel eksogen terhadap endogen sebagai berikut:

$\checkmark$ Pengaruh variabel keimanan (X1) terhadap variabel kinerja (Y) menghasilkan nilai koefisien jalur pada kolom sampel asli $=0.279$ dan nilai $\mathrm{P}$-Values $=0.003(<0.05)$ yaitu menunjukan pengaruh yang positif dan signifikan. Artinya keimanan berpengaruh positif dan signifikan terhadap kinerja atau dapat diinterpretasikan bahwa kinerja karyawan muslim PT. Inalum akan meningkat apabila didampingi oleh iman yang kuat.

$\checkmark$ Pengaruh variabel kehidupan (X2) terhadap variabel kinerja (Y) menghasilkan nilai koefisien jalur pada kolom sampel asli $=0.147$ dan nilai $\mathrm{P}$-Values $=0.011(<0.05)$ yaitu menunjukan pengaruh yang positif dan signifikan. Artinya kehidupan berpengaruh positif dan signifikan terhadap kinerja atau dapat diinterpretasikan bahwa kinerja karyawan muslim PT. Inalum akan meningkat apabilaperusahaan mampu meningkatkan taraf hidup karyawannya.

$\checkmark$ Pengaruh variabel kecerdasan (X3) terhadap variabel kinerja (Y) menghasilkan nilai koefisien jalur pada kolom sampel asli $=0.217$ dan nilai P-Values $=0.005(<0.05)$ yaitu menunjukan pengaruh yang positif dan signifikan. Artinya kecerdasan berpengaruh positif dan signifikan terhadap kinerja atau dapat diinterpretasikan bahwa kinerja karyawan muslim PT. Inalum akan meningkat apabilaperusahaan mengembangkan pengetahuan dan keterampilan karyawannya.

$\checkmark$ Pengaruh variabel keturunan (X4) terhadap variabel kinerja (Y) menghasilkan nilai koefisien jalur pada kolom sampel asli $=0.272$ dan nilai $\mathrm{P}$-Values $=$ 
0.007 (< 0.05) yaitu menunjukan pengaruh yang positif dan signifikan. Artinya keturunan berpengaruh positif dan signifikan terhadap kinerja atau dapat diinterpretasikan bahwa kinerja karyawan muslim PT. Inalum akan meningkat apabila perusahaan melakukan peberdayaan karyawan dengan baik dan benar.

$\checkmark$ Pengaruh variabel Harta (X5) terhadap variabel kinerja (Y) menghasilkan nilai koefisien jalur $=0.224$ dan nilai P-Values $=0.010(<0.05)$ yaitu menunjukan pengaruh yang positif dan signifikan. Artinya harta berpengaruh positif dan signifikan terhadap kinerja atau dapat diinterpretasikan bahwa kinerja karyawan muslim PT. Inalum akan meningkat apabila perusahaan dapat memberikan dan memenuhi keperluan atau kebutuan materialistis pada karyawannya.

Tabel 9 R-Square

\begin{tabular}{|r|rrrrr|}
\hline & Sampel Asli (0) & Rata-rata Sampel (M) & Standar Deviasi (STDEV) & T Statistik (| O/STDEV ) & P Values \\
\hline Y & 0.808 & 0.829 & 0.036 & 22.320 & 0.000 \\
\hline
\end{tabular}

Sumber: Data primer 2019 diolah dari SmartPLS

Bedasarkan tabel diatas menjelaskan bahwa dari sampel asli terdapat nilai sebesar0.808 atau $80.8 \%$ dan nilai $P$-Value sebesar 0.000 (< 0.05$)$, dapat diinterpretasikan bahwa sebesar $80.8 \%$ dari $100 \%$ secara simultan variabel eksogen dalam penelitian ini mempengaruhi varabel endogen (kinerja) dan sisanya $19.2 \%$ merupakan variabel lain diluar model penelitian ini.

\section{Kesimpulan}

Berdasarkan hasil pengukuran kinerja dari 5 aspek Maqasid Al-Syariah kinerja karyawan PT. INALUM memperoleh skor 89,9\% lebih besar dari 60\% dengan demikian kinerja Islamic human Resources PT. INALUM memiliki kinerja yang efektif. Terdapat pengaruh positif dan signifikan secara simultan seluruh variabel bebas (keimanan, kehidupan, kecerdasan, keturunan, dan harta) terhadap variabel terikat (kinerja). Hal ini dapat dilihat pada $R$-Square nilai dari sampel asli sebesar 0,808 (Positif), nilai $P$-Value sebesar $0,000<0,05$ dan nilai $\mathrm{T}$ Statistik $22.320>1,996$ (Signifikan). Hal tersebut menunjukan 80,8\% kinerja Islamic human resources pada PT. INALUM dipengaruhi oleh 5 aspek Maqasid Al-Syariah yaitu keimanan, kehidupan, kecerdasan, keturunan, dan harta 
sementara sisanya sebesar 19,2\% dipengaruhi oleh variabel diluar dari penelitian ini. Berarti kinerja Islamic human resources pada PT. INALUM dapat meningkat disebabkan oleh kelima faktor dalam penelitian ini yaitu (keimanan, kehidupan, kecerdasan, keturunan, dan harta).

\section{Saran}

Berdasarkan hasil penelitian, kesimpulan dan keterbatasan peneliti, peneliti memberikan beberapa saran untuk kedepannya sebagai berikut

1. Penelitian ini sebatas menganalisis aspek Maqasid Al-Syariah dalam mempengaruhi kinerja Islamic human resources pada PT. INALUM. Dilakukan dengan metode Mix Method. Tentunya penelitian ini tidak boleh dianggap konklusif namun memerlukan penelitian lebih lanjut untuk memvalidasi temuan ini. Karena dalam melakukan penelitian ini, penulis menyadari adanya beberapa keterbatasan sehingga bisa berpengaruh terhadap kualitas penelitian ini. Di antara keterbatasan sebagai pegawai sehingga penulis harus pintar dalam membagi waktu antara pengerjaan tugas sebagai pegawai dengan pengerjaan penelitian tersebut .

2. Kebaruan dari penelitian ini adalah mengalihkan penelitian kualitatif ke kuantitatif yaitu menganalisis aspek-aspek Maqasid Al-Syariah yang mempengaruhi kinerja Islamic human resources dengan pendekatan maslahah scorecard yang dievaluasi untuk melihat pengaruh dari aspek-aspek maqasid al-syariah terhadap kinerja karyawan muslim (Islamic human resources) untuk melihat efektifitas kinerja.

3. Penelitian ini dapat membuka jalan bagi peneliti selanjutnya agar dapat melakukan kajian mendalam mengenai faktor-faktor yang mempengaruhi kinerja Islamic human resources dan dapat dijadikan referensi mengenai teori kinerja.

4. Hasil penelitian ini dapat dijadikan informasi dan metode terhadap perusaan dalam cara mengukur dan mengevaluasi kinerja karyawannya dengan melihat aspek kesejahteraannya yang terangkum pada aspek-aspek maqasid alsyariah agar dapat menjadi sarana dalam hal untuk menentukan efektifitas kinerja karyawannya. 


\section{DAFTAR PUSTAKA}

Haluty, Djaelany, Islam Dan Manajemen Sumber Daya Manusia Yang Berkualitas, Volume. 10 Nomor 1, Juni 2014.

Suripto, Teguh, Manajemen SDM Dalam Persfektif Ekonomi Islam. Jurnal Ekonomi Syariah Indonesia, Vol. 2, 2012.

Wikaningrum, Tri, Praktek Dan Kebijakan Manajemen Sumber Daya Manusia Pada Perbankan Syariah. Vol. 15, 2011.

Zarkasi, Achmad, Analisis Kinerja Sumber Daya ManusiaPada Asuransi Jiwa Bringin Life. Skripsi, Fakultas Syariah dan Hukum UIN Syarif Hidayahtullah Jakarta. 2011.

Ramadhan, Bagus Mohammad dan Muhammad Nafik Hadi Ryandono, Etos Kerja Islam Pada Kinerja Bisnis Pedagang Muslim Pasar Besar Kota Madiun, Jurnal JESTT, Vol. 2, 2015.

Riniwati, Harsuko, Manajemen Sumberdaya Manusia. UB Press : Malang. 2016.

Musyaddad, Kholid, Prinsip Prinsip Manajemen Sumber Daya Manusia Dalam Perspektif Islam dalam Jurnal Al-Fikrah, Vol. 5, 2014.

Triyuwono, Iwan, Organisasi Dan Akuntasi Syariah,(Jember : LKis, 2000),

Khan, Bilal, Ayesha Farooq dan Zareen Hussain. Human Resource Management: An Islamic Perspective. Jurnal Business Administration, Vol. 2, 2010.

Haryani, Eni, Analisis Pengukuran Kinerja Universitas Islam Negeri Sumatera Utara Medan Berdasarkan Maslahah Scorecard. Tesis program Pascasarjan Universitas Negeri Islam Sumatera Utara. 2018.

Firdaus, Ahmad, Maslahah Scorecard (MaSC), Sistem Pengukuran Kinerja Bisnis Berbasis Maqosid Syari'ah, Jakarta: Islamic Banking \& Finance Conferences, Fakultas Ekonomi dan Bisnis, UIN Syarif Hidayatullah. 2012.

Rusindiyanto,Analisis Kinerja Sumber Daya Manusia Dengan Metode Human Resources Scorecard (HRSC) (Studi Kasus Di Pt. Arto Metal Internasional Sidoarjo), dalam Jurnal Penelitian Ilmu Teknik, Vol. 9, 2009.

Alam, Anjur Perkasa, Analisis Kinerja Karyawan Pada Pt. Bank Syariah Mandiri Cabang Aksara Medan Ditinjaudari Manajemen Syariah. Jurnal Analytica Islamica, Vol. 5, 2016.

Ascarya, Siti Rahmawati dan Raditya Sukmana, Measuring The Islamicity of Islamic Bank In Indonesia And Other Countries Based On Shari'ah Objectives. Jakarta: Center for Central Banking Research and Education, 
Bank Indonesia, 2016. Manajemen Kinerja. Jakarta: PT Rajagrafindo Persada. 2007.

\section{Catatan}

${ }^{1}$ Tri Wikaningrum, "Praktek Dan Kebijakan Manajemen Sumber Daya Manusia Pada Perbankan Syariah," dalam Jurnal Siasat Bisnis, Vol. 15, 2011, h. 99,

2 Djaelany Haluty, ”Islam Dan Manajemen Sumber Daya Manusia Yang Berkualitas", Volume. 10 Nomor 1, Juni 2014 h.70.

3 Teguh Suripto, "Manajemen SDM Dalam Persfektif Ekonomi Islam", dalam Jurnal Ekonomi Syariah Indonesia, Vol. 2, 2012, h. 240

${ }^{4}$ Tri Wikaningrum, "Praktek Dan Kebijakan Manajemen Sumber Daya Manusia Pada Perbankan Syariah", h. 100.

5 Achmad Zarkasi, "Analisis Kinerja Sumber Daya ManusiaPada Asuransi Jiwa Bringin Life" (Skripsi, Fakultas Syariah dan Hukum UIN Syarif Hidayahtullah Jakarta, 2011), h. 21.

${ }^{6}$ Harsuko Riniwati, Manajemen Sumberdaya Manusia, (UB Press : Malang, 2016), h. 1

${ }^{7}$ Kholid Musyaddad, "Prinsip Prinsip Manajemen Sumber Daya Manusia Dalam Perspektif Islam”, dalam Jurnal Al-Fikrah, Vol. 5, 2014, h. 9.

${ }^{8}$ Iwan Triyuwono, Organisasi Dan Akuntasi Syariah,(Jember : LKis, 2000), h. 253.

9 Bilal Khan, Ayesha Farooq dan Zareen Hussain, "Human Resource Management: An Islamic Perspective”, dalam Jurnal Business Administration, Vol. 2, 2010. h. 19

${ }^{10}$ Eni Haryani, “Analisis Pengukuran Kinerja Universitas Islam Negeri Sumatera Utara Medan Berdasarkan Maslahah Scorecard", Tesis, program Pascasarjan Universitas Negeri Islam Sumtera utara, 2018), h. 42.

11 Ibid,

${ }^{12}$ Ibid

${ }^{13}$ Bilal Khan, Ayesha Farooq dan Zareen Hussain, "Human Resource Management: An Islamic Perspective”, h.27.

${ }^{14}$ Ibid

${ }^{15}$ Departemen Agama RI, “Al-Qur.an dan Tafsirnya”, At- Taubah/ 9:105, h. 213.

${ }^{16}$ Bagus Mohammad Ramadhan dan Muhammad Nafik Hadi Ryandono, Etos Kerja Islam Pada Kinerja Bisnis Pedagang Muslim Pasar Besar Kota Madiun, dalam Jurnal JESTT, Vol. 2, 2015, h. 281

17 Ahmad Firdaus, Maslahah Scorecard (MaSC), Sistem Pengukuran Kinerja Bisnis Berbasis Maqosid Syari'ah, (Jakarta: Islamic Banking \& Finance Conferences, Fakultas Ekonomi dan Bisnis, UIN Syarif Hidayatullah), September 2012, h. 4.

18 Eni Haryani, “Analisis Pengukuran Kinerja Universitas Islam Negeri Sumatera Utara Medan Berdasarkan Maslahah Scorecard", h. 23. 
300 AT-TA WASSUTH: Jurnal Ekonomi Islam, Volume IV No. 2 Juli Desember 2019: 277 - 300

${ }^{19}$ Wibowo, Manajemen Kinerja, Jakarta: PT Rajagrafindo Persada, 2007, h.319

20 Rusindiyanto,"Analisis Kinerja Sumber Daya Manusia Dengan Metode Human Resources Scorecard (Hrsc) (Studi Kasus Di Pt. Arto Metal Internasional Sidoarjo)", dalam Jurnal Penelitian Ilmu Teknik, Vol.9, 2009, h.123.

${ }^{21}$ Anjur Perkasa Alam, "Analisis Kinerja Karyawan Pada Pt. Bank Syariah Mandiri Cabang Aksara Medan Ditinjaudari Manajemen Syariah”, h.6,

${ }^{22}$ Ascarya, Siti Rahmawati dan Raditya Sukmana, Measuring The Islamicity Of Islamic Bank In Indonesia And Other Countries Based On Shari'ah Objectives, (Jakarta: Center for Central Banking Research and Education, Bank Indonesia, 2016), h. 3.

${ }^{23} \mathrm{Ibid}$, h. 6.

${ }^{24} \mathrm{Ibid}$

${ }^{25}$ Eni Haryani, "Analisis Pengukuran Kinerja Universitas Islam Negeri Sumatera Utara Medan Berdasarkan Maslahah Scorecard". h. 37

${ }^{26}$ Ibid

${ }^{27}$ Ascarya, Siti Rahmawati dan Raditya Sukmana, Measuring The Islamicity Of Islamic Bank In Indonesia And Other Countries Based On Shari'ah Objectives, h. 4.

${ }^{28} \mathrm{Ibid}$, h. 14. 